\title{
Symposium
}

\section{Introduction: Property Rules as Remedies}

\author{
Emily Sherwin ${ }^{\dagger}$
}

Twenty-five years ago Guido Calabresi and Douglas Melamed proposed that we might look at legal rights and duties in a new way.' Their insight was that in the process of assigning rights and duties, two distinct decisions must be made. First, who should hold the entitlement? That is, whose interest should be supported by law when interests conflict? Second, how should the entitlement be protected? The entitlement might be backed by a property rule, which promises state intervention to prevent involuntary transfers from the holder of the entitlement to others. Alternatively, it might be backed only by a liability rule, which requires those who would take or violate the entitlement to pay a price set by the state.

The choice between property rules and liability rules has important consequences for the process by which entitlements change hands. When an entitlement is protected by a property rule, it can only be acquired with the holder's consent, at the price he demands. When it is protected by a liability rule, it can be taken without consent, at the price fixed by the state.? Occasionally the state may choose instead to prohibit both voluntary and involuntary transfers-to make the entitlement inalienable. ${ }^{3}$

After presenting this picture of legal rights and duties, Calabresi and Melamed outlined possible reasons for choosing one method of protecting entitlements over another. Central among these was the observation that while property rules promote an efficient process of exchange when transaction costs are low, liability rules are more likely to promote efficient exchanges when the

$\dagger$ Professor of Law, University of San Diego. Thanks to Larry Alexander. Kevin Cole. Cynthua Lee, Mike Rappapon, Maimon Schwarzschild. Edmund Ursin. Paul Wohlmuth, and Chns Wonnell for helpful comments.

1. See Guido Calabresi \& A. Douglas Melamed, Properny Rules. Labiliny Rules, and Inahenabuliry: One View of the Cathedral, 85 HARv. L. REv. 1089 (1972).

2. See id. at 1092 .

3. See id. at 1092-93. 
costs of bargaining are prohibitively high. ${ }^{4}$ This thought and the analytical framework on which it rests immediately caught the interest of the legal academy and have held it ever since. ${ }^{5}$

The essays collected here honor the twenty-fifth anniversary of Property Rules, Liability Rules, and Inalienability: One View of the Cathedral and continue the discussion this great article has generated. Richard Epstein makes the case for a legal regime in which property rules predominate and liability rules are reserved for cases of necessity and large-scale holdout problems subject to appropriate institutional safeguards. James Krier and Stewart Schwab explore generally, through the use of citation analysis, the continuing importance of The Cathedral to legal scholarship. Saul Levmore explains how the framework originally proposed by Calabresi and Melamed has been expanded to cover a larger range of remedies, including restitutionary combinations that could be used to force information from litigants. Carol Rose identifies the "shadow examples" that stand behind The Cathedral and some of its progeny, and uses these examples to point out differences among the traditional legal categories of tort, contract, and property.

Because these essays were prepared for a panel on remedies, I would like to add a comment on the remedial character of property rules and liability rules. The literature on property rules and liability rules proposes various criteria for choosing among remedies, but it is largely silent on the form in which these criteria should be cast. ${ }^{6}$ In other words, should remedial decisions be governed by determinate rules or indeterminate standards? ${ }^{7}$ In this

4. See id. at 1106-07. Calabresi and Melamed also discuss possible distributive advantages of liabllity rules. See id. at 1110.

5. Notable examples of the academy's continued interest in the property/liability rule distinction include A. MrTCHELL POLINSKY, AN INTRODUction To LAW AND Economics 15-25 (1989); Ian Ayres \& Eric Talley, Solomonic Bargaining: Dividing a Legal Entitlement to Facilitate Coasian Trade, 104 YALB L.J. 1027, 1036-72 (1995); Jules L. Coleman \& Jody Kraus, Rethinking the Theory of Legal Rights, 95 YALE L.J. 1335 (1986); Richard Craswell, Property Rules and Liability Rules in Unconscionability and Related Doctrines, 60 U. CHI. L. REV. 1 (1993); Louis Kaplow \& Steven Shavell, Property Rules Versus Liability Rules: An Economic Analysis, 109 HARV. L. REV. 713 (1996); James E. Krier \& Stewart J. Schwab, Property Rules and Liability Rules: The Cathedral in Another Light, 70 N.Y.U. L. REv. 440 (1995); Dale A. Nance, Guidance Rules and Enforcement Rules: A Better View of the Cathedral (1996) (unpublished manuscript, on file with author). Other theorists have also explored the implications of inalienable rights. See, e.g., Margaret Jane Radin, Market-Inalienability, 100 HARV. L. REV. 1849 (1987); Susan Rose-Ackerman, Inalienability and the Theory of Property Rights, 85 CoLUM. L. REV. 931 (1985).

6. Ian Ayres and Eric Talley have suggested that uncertainty about entitlements and their protection may promote efficient bargaining. See Ayres \& Talley, supra note 5, at 1034-35, 1073-78; see also Jason Scott Johnston, Bargaining Under Rules Versus Standards, 11 J.L. EcoN. \& ORG. 256 (1995) (explaining how "contingent, ex post" entitlement may promote bargaining if ex post balancing by courts is expected to be imperfect).

7. By "rules," I mean prescriptions that are phrased in determinate language and require a certain outcome in an identifiable set of cases. The import of a rule is that those to whom it is addressed should act as prescribed without further consideration of its underlying purposes and ideals. These qualities of determinacy and generality enable the rule to hold its shape and meaning in a variety of settings over time, thereby giving prospective definition to legal rights. They differ from open-ended decisional standards, which invite decisionmakers to engage in normative evaluation of particular facts at the time the standard is applied. For much fuller analyses of rules and the problem of form, see FREDERICK SCHAUER, PLAYINO BY THE RULES: A PHILOSOPHICAL EXAMINATION OF RULE-BASED DECISION-MAKINO IN LAW AND IN LIFB 
Introduction, I point out that judicial practice strongly favors case-by-case decisionmaking under loosely defined standards, and I discuss some of the implications that follow.

In the area of criminal law, statutes identify a determinate core of entitlements protected by property rules. ${ }^{8}$ But apart from crime, the great body of property rules are enforced by courts through equitable remedies such as injunctions and specific performance-remedies that historically have been surrounded by a cloud of judicial discretion. ${ }^{9}$ The first doctrinal hurdle for the granting of an injunction is the ancient maxim that equitable relief is available only when damages are inadequate to provide full relief. ${ }^{10}$ To some extent, cases in which damages are inadequate can be sorted into categories, but these have never been reduced to fixed rules and, if anything, the standard of adequacy has become vaguer and more fact-dependent over time." Further, even when damages admittedly are inadequate, a collection of notoriously

(1991); Larry Alexander \& Emily Sherwin, The Deceptrve Noture of Rules, 142 U PA L. REV 1191 (1994); Isaac Ehrlich \& Richard A. Posner, An Economic Analysis of Legal Rulemakng. 3 J. LEGAL. STUD 257 (1974); Louis Kaplow, Rules Versus Standards: An Economic Analysis, 42 DuKE L\} 557 (1992). Duncan Kennedy, Form and Subsiance in Privare Law Adjudication, 89 HARV L REV 1685 (1976): William Powers, Jr., Structural Aspects of the Impact of Law on Mtoral Duty Withn Unhtananusm and Social Contract Theory, 26 UCLA L. REV. 1263 (1979): Carol M. Rose. Cnjstals and Mfud in Propern Law, 40 STAN. L. REV. 577 (1988).

8. Even here the determinacy of these property rules ts tempered somewhat by prosecutonal discretion in pressing charges and judicial discretion over sentencing, and recent efforts to impose determunate sentencing rules on courts have met with much judicial resistance. See People v Romero, 917 P 2u 628 (Cal. 1996) (interpreting California's "three strikes" law to allow judge to strike pror felony convicuons in furtherance of justice); José A. Cabranes, Sentencing Guddelunes: A Dusmal Faulure. N Y LJ.. Feb 11. 1992 , at 2.

9. See F.W. MATTLAND, EQUTTY 1-11 (2d ed. 1936) (describing hustory of cquily). I JOHN NokTUN POMEROY, A TREATISE ON EQUTTY JURISPRUDENCE $\S \S 43-67$ (Sth ed. 1941) (describing moral preccpls in equity jurisprudence); 1 JOSEPH STORY, COMMENTARIES ON EQUTTY JURISPRUDENCE $\$ 206$ (discussing role of ethics in equity) (13th ed. 1886). The same can be sald of restitutionary remedies, which are governed by the notoriously indeterminate standard of "unjust enrichment." See generally Jorlx $P$ DAWSON, UNJUST ENRICHMENT (1951) (discussing history and nature of restitution)

10. See Dan B. Dobbs, LAW of Remedies 166 ( $2 \mathrm{~d}$ ed. 1993)

11. See RESTATEMENT (SECOND) OF TORTS § 938 (1965) (noung "relauve adequacy" of legal and equitable remedies). For a thorough analysis of the history and current status of the requirement that damages be inadequate and the corresponding requirement of imeparable injury. see DovGLAS LAYCock. THE DEATH OF THE IRREPARABLE INJURY RULE I-24 (1991)

There are some interesting parallels between these tradiuonal limits on equutable remedies and the criteria for remedial choice identified in the literature on propeny rules and liability rules Decistons holding that damages are inadequate often turn on the presence of personal, idiosyneratue values that are not reflected in market price or on the uncenainty of values over an extended penod of ume, both of which are likely to drive up errors and other costs of assessing the plaunurf's loss. See Eastem Rolling Mill Co v. Michlovitz, 145 A. 378, 384 (Md. 1929) (requiring specific performance in contract dispute where estimated value of future delivery of goods "would be speculatuve and conjectural, and not. therefore, compensatory"); Kitchen v. Herring, 42 N.C. (7 Ired. Eq.) 190, 192 (1851) (requinng spectic performance in contract dispute over land); $c f$. POLINSKY, supra note 5, at 22-24 (discussing imponance of accuracy in measuring damages); Krier \& Schwab, supra note 5, at 453-6-4 (arguing that assumed efficiency of liability rules when transaction costs are high may be undercut by high judictal "issessment costs") Judictal doctrine regarding the adequacy of damage remedies can be understood as reflecting a similar concem with assessment costs. See Kaplow \& Shavell, supra note 5, at 724-37, 759-6-4 (anguing that as long as cours can estimate average harm within class of cases, even tnaccurate liability rules are supenor to property rules, but conceding that liability rules may lose their advantage if judictal estumales of harm are systematically low). 
indeterminate equitable defenses may stand in the way of an injunction. An equitable remedy will be denied, for example, if the plaintiff has come to court with "unclean hands,"12 or if it would impose a hardship on the defendant that is "disproportionate" to the benefit it confers on the plaintiff. ${ }^{13}$ "Unclean hands" describes an indefinite class of shady conduct, while "disproportionate hardship" can only be identified by comparing the positions of particular individuals. Thus, in the most common cases, judicial decisions about whether to employ a property rule or a liability rule are not governed by fixed rules but left for case-by-case resolution under indistinct, and inevitably normative, standards.

The absence of rules for judicial choice among remedies means that property rules and liability rules, as imposed by courts, have only a limited prospective role in law. Because the identity of the remedy is uncertain until a dispute has been adjudicated, property rules and liability rules cannot serve as incentives before that time. Parties may make prelitigation decisions based on a probabilistic assessment of the outcome of litigation, ${ }^{14}$ but in the absence of fairly determinate rules dictating the choice of remedy in classes of cases, a court's eventual selection of a property rule or a liability rule will have little effect on a potential defendant's decision whether to bargain or to take without consent. Another way to put this is that property rules and liability rules, as currently administered by judges, do not operate as conduct rules. Their effect is limited to secondary decisionmakers (judges) and not to primary actors who order their conduct in the shadow of legal sanctions. ${ }^{15}$ Moreover, the existence of an array of possible remedies can change the character of the

12. See, e.g., Carmen v. Fox Film Corp., 269 F. 928, 931 (2d Cir. 1920) (denying injunctive relief due to unclean hands); RESTATEMENT (SECOND) OF TORTS $\$ 940$ (1965). See generally ZECHARIAH CHAFEB, JR., SOME PROBleMS OF EQUTTY 1-22 (1950); DOBBS, supra note 10, at 68.

13. See, e.g., Van Wagner Adver. Co. v. S\&M Enter., 492 N.E.2d 756 (N.Y. 1986) (denying specific performance due to disproportionate hardship); Patel v. Ali, [1984] 1 All E.R. 978 (Ch. 1984) (denying specific performance because of harm it would cause defendant); RESTATEMENT (SECOND) OR TORTS $\S 941$ (1965). See generally DOBBS, supra note 10, at 78-81 (discussing "balance of equities"). Equitable defenses based on "disproportionate hardship" and plaintiff's "unclean hands" also can be assimilated to some of the arguments that have appeared in favor of liability rules. Both of these defenses involve situations in which the costs of bargaining are likely to be high, either because the parties' valuations are very far apart (disproportionate hardship) or because negotiations are tainted by an acute disparity in information between parties (unclean hands). This makes liability rules, with prices fixed by the court, an attractive alternative to bargaining. For the traditional view that liability rules are superior when transaction costs are high, see POLINSKY, supra note 5, at 19; RICHARD A. POSNER, ECONOMIC ANALYSIS OF LAW 54-57 (3d ed. 1986); Calabresi \& Melamed, supra note 1, at 1106-07; and Craswell, supra note 5, at 8-9. Further, Ian Ayres and Eric Talley have argued that liability rules will induce parties to bargain to efficient outcomes, because their effect is to split the entitlement between parties. See Ian Ayres \& Eric Talley, Distinguishing Benveen Consensual and Nonconsensual Advantages of Liability Rules, 105 YALE L.J. 235, 237-38 (1996). This consideration is especially important when the parties must divide a large surplus, or, in the terminology of traditional doctrine, when the burden of an injunction is disproportionate to its benefit to the plaintiff.

14. Uncertainty about the outcome in fact may have beneficial effects on negotiations between them. See supra note 6.

15. See Meir Dan-Cohen, Decision Rules and Conduct Rules: On Acoustic Separation in Criminal Law, 97 HARV. L. REV. 625, 625-34 (1984) (discussing distinction between "conduct rules" and "decision rules"). 
underlying entitlement itself. However determinate the initial definition of the entitlement, its ultimate consequences are uncertain. ${ }^{16}$

There are several possible explanations for the courts' apparent distaste for rules in the area of remedies. The first is that they doubt that rules governing the choice of remedy can be justified. Because rules by definition are general and determinate, they inevitably will miss some cases that fall within their purposes and sweep in some cases that do not. The use of rules may nevertheless be justified if it appears that decisionmakers will reach a better sum of results (judged by the purpose of the rule) by following the rule than they would reach if they exercised their best unconstrained judgment in each case. ${ }^{17}$ This is most likely to be true when the rulemaking authority has better information than those to whom the rule is addressed, ${ }^{18}$ or when the rule is necessary to address coordination problems. ${ }^{19}$

In designing rules for choice among remedies, however, a judge has no informational advantage over judges in future cases. If anything, the situational bias of adjudication puts the judge at a disadvantage in assessing the future consequences of the rule. ${ }^{20}$ With respect to coordination, rules for choosing among remedies might well be beneficial-in fact, any argument about the prelitigation incentive effects of property rules or liability rules assumes that this is so. But the longstanding preference of courts for indistinct standards of hardship and unfairness suggests that they have not looked at remedial decisions this way. Their instinct appears to have been that the benefits of coordination are low in comparison with the benefits of careful tailoring, case by case.

Another possible explanation for judges' reluctance to announce rules for the choice of remedies is that they believe remedial discretion is necessary to the perceived legitimacy of the legal system. Members of the public are most likely to have confidence in the legal system if they can perceive its

16. Cf. Coleman \& Kraus, supra note 5, at 1342 (charactenzing entulements as "conceptual markers." "content" of which is supplied by property rules and liability rules): Maddline Moms. The Structure of Entitlements, 78 CORNELL L. REV. 822, 842-44 (1993) (questioning distinction between entuliements and their enforcement).

17. Joseph Raz has termed this the "normal justification" of politscal authonty See JOSEPH RAZ. THE MORALITY OF FREEDOM 70-80 (1986).

18. See SCHAUER, supra note 7, at 150-55, 163-66 (exploring ways in which rules reduce errors): Heidi M. Hurd, Challenging Authoriny, 100 YALE L.J. 1611.1615 (1991) (discussing "theorettcal authonty" of those in "position to give good advice concerning how another ought to act in certain circumstances").

19. See, e.g., Gerald J. Postema, Coordination and Convention at the Foundations of Law, $11 \mathrm{~J}$ LEGAL STUD. 165 (1982).

20. Suppose, for example, that a judge is considering whether to order a defendant to remove a twostory wooden building that encroaches on a parcel of land, and suppose also that the sole objectuve in such cases is efficiency. Because this judge, like all judges, sees the problem through the filter of a parucular case-how this building came to encroach on this land-there is no reason to thunk he has better information about the efficiency of injunctions in a class of future cases than the judges who eventually will preside over those cases. Therefore, he may limit his thoughts about efficiency to the facts before hum. rather than announcing a rule that injunctions should always be grantod aganst encroachments less than three stories high, or against encroachments made of wood 
importance to their own lives, and they are most likely to observe the effects of law at the remedial stage, when general laws are applied to specific facts. People do not respond to abstract propositions about the benefits of rules in the same way that they respond to tangible, specific, and proximate outcomes. Thus, when a fully justified rule yields an obviously bad result, they will be unsatisfied if the court refuses to soften the application of the rule.

As a result, it may be wise for courts to choose remedies case by case, even when a fixed rule of entitlement would produce a better sum of results over time. Of course, public faith in law will also suffer if there are large discrepancies between ex ante rules of entitlement and their remedial consequences. But at least when rights and remedies are thought of as distinct elements of law, the variety of judicial remedies available to enforce rights can serve as a safety valve, allowing courts to engage in retrospective fine-tuning of rules without appearing to alter them. ${ }^{21}$

I do not mean to endorse current remedial practice, but only to suggest some explanations for it. The two possibilities I have suggested are the absence of a "normal justification" for remedial rules and the psychological importance of tailoring remedies to specific cases. It may turn out on closer inspection that neither is persuasive and that the courts would do better by fashioning rules for the choice among remedies. Particularly if coordination of conduct in advance of (or outside) litigation is of primary importance, criteria for efficient remedial choice should be recast in a determinate form that will allow property rules and liability rules to operate prospectively. If, on the other hand, it appears that courts have been acting on sound intuition, either about the greater accuracy of case-by-case decisionmaking or about the systemic importance of remedial discretion, then analysis of property rules and liability rules should proceed on the assumption that conduct prior to litigation will not be much affected by the choice of remedy. ${ }^{22}$

21. See Rose, supra note 7, at 597-610. The choice among remedies makes it possible for a court to honor entitlements and at the same time to modify an unsatisfactory outcome by limiting claims to damages. This probably can be done without much impact on the force of the entitlement as a rule of conduct, because there is a considerable degree of natural "acoustic separation" between rules of entitlement and remedies: The public is generally aware of property rights and only dimly conscious of the complex set of remedies by which they might be enforced. The entitlement as announced may even suggest that encroachment is forbidden (a property rule), rather than permitted on condition that the encroacher pay for harm caused (a liability rule). But the language of remedies law is sufficiently arcane that ordinary observers are not likely to appreciate the significance of the remedial distinction. $C f$. Dan-Cohen, supra notc 15, at 1325-34 (analyzing acoustic separation in criminal law); Emily L. Sherwin, Law and Equity in Contract Enforcement, 50 MD. L. REv. 253, 300-14 (1991) (discussing acoustic separation in choice of legal or equitable remedies for enforcement of contracts).

22. Another implication is that the question of form should be taken into account in assessing the possibility of statutory liability rules, such as pollution taxes that allow industries to pollute and pay. See Kaplow \& Shavell, supra note 5, at 750-52 (preferring statutory liability rules, in form of pollution taxes, to statutory property rules, in form of tradeable pollution rights); Krier \& Schwab, supra note 5, at 475-77 (discussing variety of taxes and subsidies that allocate choice of action either to government or to citizens). Legislatures are more likely, and better situated, to cast remedial rules as rules. When coordination is important, legislation may be the best approach. 
My object here has been to draw attention to the problem of remedial discretion and to suggest how it might bear on the analysis of legal entitlements set forth twenty-five years ago by Calabresi and Melamed. Like so many others who have written on this subject, I am grateful to Calabresi and Melamed for their view of "the Cathedral," which has been and continues to be a wonderful incitement to thought. 
